\title{
Key biotechnology patent delayed
}

\section{Cohen-Boyer patents could face challenge}

\section{Washington}

The US Patent and Trademark Office suddenly announced on 30 June that it was delaying the issue of a second fundamental patent on genetic engineering to Stanford University and the University of California. The patent, which complements the Cohen-Boyer patent issued to the universities in December 1980, had already been assigned a patent number and was scheduled for issue on 13 July.

The announcement immediately sparked off speculation that a challenge to the patents was imminent. That speculation was fuelled by the revelation that an Exxon patent attorney, Albert Halluin, had discovered several potential defects in the original patent. Halluin's findings are to appear in a book called The Patenting of Life Forms, to be published by Cold Spring Harbor Laboratory on 15 August.

The most potentially damaging of Halluin's observations is that since the original patent was filed by Dr Stanley Cohen of Stanford and Dr Herbert Boyer of the University of California, San Francisco in November 1974, new findings have invalidated some of the information supplied in the patent specifications. The patent covers a key plasmid which is used as the vehicle for inserting new genes into the bacterium Escherichia coli and describes the method for producing this plasmid. But in 1977, Dr Cohen published a paper in Journal of Bacteriology that admits an error in the original procedure. A number of molecular geneticists have asserted that the error was substantial enough to make it impossible to duplicate Cohen's and Boyer's work from the patent description alone.

Halluin argues that deposition of the product in the American Type Culture Collection can get around such problems, but - and this is a second potential flaw in the patent - Cohen and Boyer did not deposit their plasmid until June 1981, more than six months after the patent was issued.

A third possible defect in the original patent concerns prior disclosure. A patent is not granted if information sufficient to duplicate the process is made public more than a year before application is made. Halluin points out that an article in New Scientist on 25 October 1973, more than a year before the application was filed, gives a detailed report of Cohen's and Boyer's work from what was supposed to have been an off-the-record Gordon Conference.

Halluin is chairman of the Chemical

Practice Committee of the American Patent Law Association, and the chapter he contributed to the Cold Spring Harbor book - of which only a very minor part deals with the Stanford patent - was apparently written in this capacity and not as an employee of Exxon Research and Engineering.

A spokesman for Exxon said it does not plan to challenge the validity of the Stanford patent and is not even officially studying it. He said the reason Exxon had not joined with 73 other companies in buying a one-year licence to the patent (at a price of $\$ 10,000$ ) was that it had no plans to use the process commercially.

In spite of the rumour of a challenge to the patents, none has been filed, according to Rene Tegtmeyer, the US assistant commissioner for patents. Tegtmeyer said he could not elaborate on the reasons for the delay in the second patent, but said "it happens a couple of hundred times a year" that a patent examiner requests a reexamination in the light of new information. An explanation will probably come in two or three weeks, when a patent

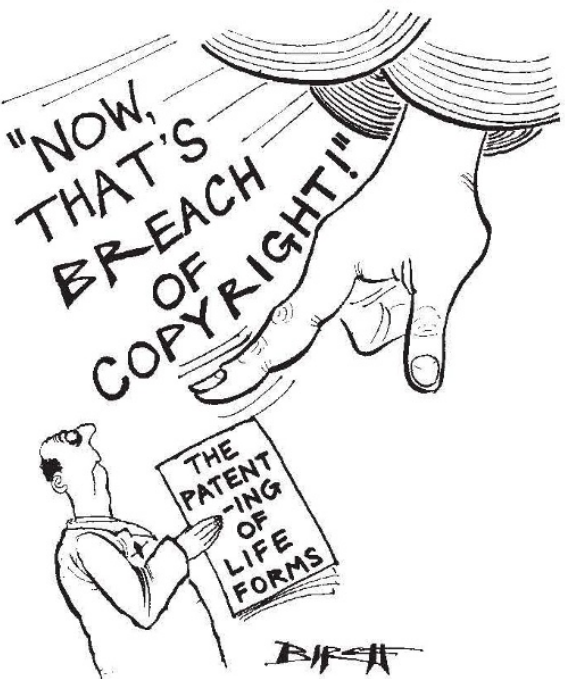

examiner is assigned to the reexamination. Normally, all such actions by the Patent Office are kept confidential. In this case, the applicant took the unusual step of opening its patent office file to public access.

Stanford's director of technology licensing, Niels Reimers, said that he was

\section{Chemical weapons denied funds}

\section{Washington}

The House of Representatives voted last week by a wide margin against the production of binary chemical weapons.

The 251-159 vote came on an amendment to the defence authorization bill which deletes $\$ 54$ million that the Reagan Administration had requested to begin production. The United States has not manufactured chemical weapons since 1969, when President Nixon ordered that production should be halted. The strength of congressional opposition to breaking that 13-year moratorium was evident when 81 Republicans broke ranks with the Administration and voted to block the funds.

The Administration wanted the new weapons as a counter to what it sees as evidence of increased Soviet production of chemical warfare agents and an increased willingness to use them. Opposition was led by Representative Clement Zablocki (Democrat, Wisconsin) and Representative Ed Bethune (Republican, Arkansas), the sponsors of the amendment, who managed to use the Administration's own argument against it. "We have an opportunity to demonstrate that we are not like the Soviets", Bethune said. "It just doesn't make sense to throw away the one shred of evidence that Americans truly yearn for the day when arms will be reduced." Zablocki argued further that to proceed with production would divide the NATO alliance, as the Europeans - with the possible exception of France - are opposed to having new chemical weapons on their soil. Opponents of production have argued that the new weapons are useless as a deterrent unless they are positioned in Europe.

The United States has a large stock of the older, unitary shells and bombs, which contain live nerve gas. Stocks are maintained in West Germany as well as the United States. The army says the binary weapons, which contain two relatively non-toxic gases that $\mathrm{mix}$ in flight to produce the nerve agent, are safer to store and to handle and are needed to replace deteriorating stocks of the older weapons.

The Senate, which in May approved the production of binary weapons by a close $49-45$ vote, is likely to accede to the House view when the two chambers confer on a final authorization bill. The House action does not affect the $\$ 705$ million that the Administration is requesting for further research and development on binary weapons and for chemical defence.

Congress last year authorized construction of a facility in Arkansas to produce the new weapons, but stopped short of authorizing production. According to Bethune, the House action this year may have been more a response to public pressure - which has apparently been heightened by reports of Soviet use of chemical weapons in Afghanistan and Soviet complicity in the "yellow rain" episodes in South East Asia - than a response to logic and reason. As one staff member said, "no one wants to get up and speak in favour of nerve gas".

Stephen Budiansky 
just as much in the dark about the delay as anybody. "In itself", however, "it's nothing momentous", he said. The issues raised by Halluin "have been looked at" and do not challenge the basic claim of Cohen and Boyer.

$\mathrm{He}$ also questioned the benefits to anybody of mounting a challenge. "Recall that the royalties are very low and no-one has contested that they [Cohen and Boyer] were the first ones to do this. And given the fact that everyone's getting a licence, I don't know why anybody would challenge it."

But royalties may not continue to be low. One industry observer pointed out that once commercial production begins especially production of products with a high mark-up - royalties could be "substantial". And the incentive to mount a challenge would also grow. The licence contracts call for royalties of 1 per cent on net sales up to $\$ 5$ million, $3 / 4$ per cent on the next $\$ 5$ million, and $1 / 2$ per cent after that.

If a challenge is eventually filed, it could well be based on the issues that Halluin raised, and would probably take the form of a request for a reexamination of the first patent. Since December 1980, it has been possible to file such a request directly with the Patent Office, a much simpler procedure than mounting a lawsuit as was previously required. A recent Supreme Court ruling allows even a licensee to challenge a patent.

The original Stanford patent was a process claim, covering the production of transformants. The second patent, a product claim, covers the transformants themselves. In practice, however, it adds relatively little: the only additional protection it provides is in preventing a foreign company from producing transformants outside the patent and then selling them in the United States.

Stephen Budiansky

\section{Polish students}

\section{Subjective change}

There threatens to be a significant drop in the numbers of Polish students reading technical subjects in the next academic year, beginning in October. According to Warsaw radio, there has been a "qualitative transformation"' of young people's attitudes to study. School-leavers, said the commentator, are thinking more frequently in "practical categories", and, in particular, of job prospects.

The swing away from technical studies does not, however, seem to be entirely spontaneous. At the end of June, the Minister of Science, Higher Education and Technology, Dr Benon Miskiewicz, said that the intake quota for the polytechnic universities had been cut this year due to a reduced demand for engineering personnel.

The minister's explanation, that the admission quotas have been deliberately cut, seems the more likely. In Poland's current economic stagnation, many of the grandiose engineering projects of the Gierek regime have been suspended or, tacitly, cancelled. Moreover, since the alternative to higher education for male school-leavers is military service, it seems highly unlikely that many would deliberately opt for the latter.

Unlike many of its allies, Poland has never attempted to plan university admissions strictly in accordance with job prospects. The ministry has, however, the right to set limits to admissions in subjects that are over-subscribed - a right hotly contested during the public debate on the draft higher education act last year. A parallel situation exists in the medical colleges, where the Ministry of Health can intervene on admission numbers but where, in recent years, the ministry has been pressing for more admissions even though teaching facilities are inadequate.

Last September, the Warsaw Medical Academy took advantage of the then liberalization to reduce its student intake - and triggered a sit-in by the parents of students who had failed to gain admission. Significantly, however, neither the Ministry of Health nor Solidarity and its student adjunct, the Independent Students' Association NZS, backed the parents, on the grounds that the decision must rest with the academy.

Unemployment among young graduates has been a problem in Poland for several years, until the imposition of martial law on 13 December 1981, with its system of compulsory registration and direction toif necessary - unskilled manual labour.

Part of the explanation is that student admissions have been uncontrolled. University tuition in Poland is free, textbook prices are low, and during the 1970 s artificially pegged food prices made it relatively easy for all but the poorest families to support their children through five or six years of higher education. Recent moves to adjust the price structure have, however, produced increases so high that many citizens cannot afford to purchase their (at best scanty) food rations, so that keeping a son or daughter at university is fast becoming a luxury. A system of maintenance grants and/or loans is being considered, which would, presumably, allow the ministry to regulate admissions without having to decree a numerus clausus on admissions. It could also, in the long term, help to end the controversial system of "bonus points" by which young people from working class or peasant families receive extra marks in the university entrance examination to compensate for the lack of intellectual background at home. It could also (although this has not been mentioned publicly) provide the ministry with a further means of controlling student unrest without encroaching on university autonomy by ordering that offending students should be expelled or suspended.

\section{British nuclear power \\ Risks assessed}

The British Central Electricity Generating Board (CEGB) published a final appendix to its case for building a pressurized water reactor (PWR) in the nick of time last week, just one working day before the public inquiry into the siting of the reactor at Sizewell in Suffolk opened this Monday (26 July). The publication of appendix $\mathbf{M}$, on degraded core accidents and their consequences, added the last few kilogrammes to the more than 100 kilogrammes of reading matter that is CEGB's statement.

Participants at the inquiry, however,

\section{The Sizewell inquiry}

Organizing the Sizewell inquiry is by no means simple, to judge from the length of meetings set aside for the task. The hearings earlier this week were the second in a series of three to discuss the precise procedure of the main inquiry, beginning on 11 January 1983.

The Department of Energy has promised a wide-ranging inquiry that will consider the need for the proposed pressurized water reactor (PWR) in the light of the government's long-term energy policy, the safety of the design, waste management and local environmental issues. Sir Frank Layfield, the inspector, favours hearing evidence topic by topic rather than each organization making its complete case in one session as at the Windscale inquiry. The order of witnesses is expected to be the Central Electricity Generating Board (CEGB) followed by government departments and other statutory bodies, local authorities, objector groups and individual objectors, although the order may well depend on the topic.

The procedural hearings are designed to help the inspector to determine precisely how to order the main inquiry for example, how to split topics and what guidelines to issue on the release of documents. The formal opening of the inquiry this week gives the inspector statutory powers to request documents he believes should be made available before the main hearing. The inspector seemed eager to take up those powers on Monday when he promised to draw up guidelines on the release of documents that have not been voluntarily disclosed.

The inquiry is planned to take place at the Maltings, Snape, the closest large meeting place to the proposed site. But the inspector has suggested that part of the inquiry, perhaps during June and July 1983, should transfer to London in view of the national importance of much of the debate. Some objectors will be arguing the case for holding more of the hearings in the capital, especially those on need and economies. 